\title{
Effect of Tutorial Instructional Strategy and Drill in Using MYOB Accounting in Vocational High School Bekasi West Java Province
}

\author{
Heru Sriyono \\ University of Indraprasta PGR Jakarta, Indonesia \\ herusriyono2@gmail.com
}

\begin{abstract}
This study aimed to analyze the application of learning strategies and Drill tutorials on the capabilities of MYOB Accounting. This study uses a quasi-experimental method by using analysis of variance by F test population of this study in Class XI student Vocational School District Bekasi City, West Java province in the academic year 2015/2016. Samples were obtained through a simple random sampling technique, namely the Vocational high School 1 (one) as an experimental class Tutorial instructional strategy and Vocational High School 11 (eleven) class control with Drill instructional strategy. Collecting data using a test on the ability MYOB Accounting. The results showed that the ability of MYOB Accounting Students who use tutorial learning strategy is better than learning strategies Drill.
\end{abstract}

Keywords: Instructional Strategies, Tutorial, Drill, MYOB Accounting, Vocational High School

\section{Introduction}

Bekasi is a city in West Java province and one town Industry in Indonesia. Industrial development in this city requires a workforce ready to use so much growth Vocational middle school in Bekasi. Demands muchneeded employment is the field of accounting expertise. Learning accounting must be in accordance with market needs in financial calculations, one of which is MYOB Accounting program. Accounting application programs for vocational students in the accounting field very rapidly once its development and of many kinds. Some computer application program in accounting that many circulating in Indonesia is MYOB Accounting. Based on the observation that has been made in getting that use MYOB accounting by students is still very difficult, so it takes a special instructional strategies for teachers to obtain maximum results. Students categorize accounting subjects as a bogey just like Mathematics, English, and others. But in reality accounting graduate students are required to have a minimum competence in the standard of competence in the accounting subjects, which can achieve the minimum completeness criteria (KKM) for theory and practice in the preparation of financial statements for the company's services and trade. To reach KKM or competencies that have been set are certainly many factors that must be considered. Factors such as curriculum, teacher, student, learning, administration, learning tools, and so forth. But of the many factors that exist, the role of accounting learning strategies in achieving the goals or competencies highly effective accounting subjects that affect student learning outcomes.

MYOB Accounting required for learning specific learning strategies for learning strategy use accounting application program emphasizes cognitive interaction between the students, the subject matter and the computers that have been programmed. Through this strategy the student will perform continuous active interaction with the accounting application program and the teacher only as a director or facilitator. The interaction with the students are expected to master the subject matter easily because students can interact directly with the computer system has been programmed so that learning can be more interesting and fun to learn. Of the various learning strategies using the program for the accounting application of existing accounting subjects, two of which will be its effectiveness are: (1) learning strategies using the application program accounting drills and (2) learning strategies using the accounting application tutorial program. Learning drills is one of learning that emphasizes learning by road train students on the lesson material that has been given (Rusman, 2011). Drills will be implanted through certain habits in the form of exercise. With continuous practice, it will be embedded and then it will become a habit. In addition, in order to inculcate the habit, these drills can also increase the speed, accuracy, completeness of doing things and can also be used as a way to repeat the training material that has been presented, it can also increase the speed. While learning tutorial is one of learning that emphasizes the use of software which contains a guide / tutorial to solve the problems of accounting practice. Tutorial has several objectives, namely: (1) To improve the control of the students' knowledge in accordance with that contained in the learning software: do the efforts of the relevant material enrichment; (2) to improve students' abilities and skills on how to solve problems, overcome 
difficulties or obstacles to be able to guide themselves; and (3) to improve the students on how to learn independently and apply it to each of the CBI (Computer Based Instruction) being studied. This study aimed to determine the effect tutorial learning strategy with a drill on the ability to use MYOB accounting on students SMK Kota Bekasi West Java province.

\section{Literature Review}

ATM is well established in the general use of ICT in learning activities in the classroom. Even the government announced that by 2015 about $70 \%$ of all schools in Indonesia must be literate to ICT connected to the Internet networking (Ariyani and Haryanto, 2010). Therefore, creation of software learning applications are many and circulated throughout the bookstore to facilitate the success of government programs. Learning application program for vocational students in the accounting field very rapidly once its development and of many kinds. Some computer application program in accounting that many in Indonesia, among others DacEaasy Accounting, General Ledger, MYOB Asset Manager, MYOB Accounting, MYOB Premiere, Peachtree Complete Accounting, Accurate Accounting, Excel Accounting, Simply Accounting Plus, Accurate Accounting, Zahir and other accounting application program. From several application programs such outstanding one for accounting computer application program that is very popular is MYOB Accounting (Sudarmanto, 2005). MYOB Accounting is an accounting software designed for small and medium enterprises (SMEs) are made integrally with computer aids in vocational subjects MYOB Accounting belongs to the part of the accounting subjects. According Sudarmanto (2005) and Arifin (2001), the notion of MYOB Accounting is a computer application program (software) that is specifically designed to record economic transactions expressed in units of money (accounting data) and make financial reports for companies or tuitions certain institutions both with the purpose of profit and with social goals in order to present financial information in a certain period quickly and accurately.

MYOB Accounting Program who have thrived have advantages when compared with other accounting applications program. Some of the advantages of this MYOB Accounting program including the following:

- Easy to understand and constraints to operate very small when compared with other accounting applications program.

- This software is in accordance with GAAP (Financial Accounting Standards) prevailing in Indonesia and also with GAAP (General Accepted Accounting Principles) and thus no longer hold a significant modification.

- The module contained in very complete software MYOB Accounting so that corporate users need not worry about the changes.

- MYOB Accounting is able to handle transactions that have very great value. This software is able to record transactions with a value of up to one billion rupiah (Sudarmanto, 2005).

Rusman (2011) learning drills are a way of learning to train students on the lesson material that has been given. Drills will be implanted through certain habits in the form of exercise. With continuous practice, it will be embedded and then it will become a habit. In addition, in order to inculcate the habit, these drills can also increase the speed, accuracy, completeness of doing things and can also be used as a way to repeat the training material that has been presented, it can also increase the speed. According to Ibrahim and Syaodah (2010), Roestiyah (2008) and Suwarno (2005) drill is a way of teaching by providing exercises to what students learned So that acquire a certain skill. According Djamarah and Zain (2006) and Adhegora (2012) method of exercise training method is also called, is a good way of teaching to inculcate certain habits, which are used to gain agility, accuracy, opportunity, and skills. Here are the steps in the training method according to a modification of Heryawan (2010). a.Before the exercises carried out, students should be given an explanation as to the meaning or the benefits and purpose of the exercise. b. Exercise should be done gradually, starting from simple then to the extent that more complex or difficult. c. During the on-going exercise, consider which parts are most of the children was difficult. d. Practice parts that it is difficult that more intensive. e. Individual differences in children need to be considered.

Tutorial is defined as a form of specialized learning with qualified coaching, the use of micro-computers for learning tutorial. Or with any other explanation that the tutorial is learning guidance in the form of referrals, 
assistance, guidance, and motivation for students to learn efficiently and effectively. Providing assistance means helping students to learn the subject matter. Instructions means providing information on how to learn efficiently and effectively. Referral means directing students to achieve, the purpose of each. Motivation means the operations of the students in learning the material, tasks, and taking the assessment. Tutoring means helping students solve learning problems. According Heinich et al. (1982) programmed tutoring is the learning principles that programmed instruction: (a) the presentation of Information Appropriate to the student's current ability, (b) frequent opportunities to respond to the material, (c) immediate feedback / correction. According to Warsito (2008) this program is a program that is in the delivery of material is done in the tutorial, as befits a tutorial that teachers or instructors. The information contains a draft text presented either still or moving images, and graphics. At the appropriate moment, namely when it is considered that the student has read, interpret and absorb the concept, put forward a series of questions or tasks. If the student answers or responses correctly, then proceed with the next material. If the answer or response to one student, then the student must repeat understand the concept as a whole or in certain parts only or student must make improvements or remedial. Then in the final part will be given a series of questions which is a test to measure the level of students' understanding of the concept or the material presented. Rusman (2011) describes some tutorial learning objectives, namely: (1) To improve the control of the students' knowledge in accordance with that contained in the learning software: do the efforts of the relevant material enrichment; (2) to improve students' abilities and skills on how to solve problems, overcome difficulties or obstacles to be able to guide themselves; and (3) to improve the students on how to learn independently and apply it to each of the CBI is being studied

\section{Methodology}

This study uses a quasi-experimental population in Class XI student of vocational high school Bekasi West Java province in the academic year 2015/2016, amounting to 5 (five) classes. Samples were obtained through a simple random sampling technique, ie selecting 2 (two) of 5 (five) class. The sampling results obtained, namely SMK 1 (one) as an experimental class Tutorial instructional Strategies by the number of respondents 30 people and SMK 11 (eleven) class control with Drill instructional strstegy with the number of respondents 30 people. Collection data MYOB accounting students performed with a test on the students after the experiment is performed. Test MYOB accounting previously tested the validity and reliability to students outside the study sample. Data analysis was performed using analysis of variance with test $\mathrm{F}$.

\section{Results}

Analysis of the data of student learning outcomes were performed using ANOVA that calculation was helped by SPSS 20. Results of the ANOVA test followed by $\mathrm{F}$ test to determine the significance of the differences between each group was significantly (simple effect). In other words, the F test is used for the purpose of seeing where the sample group were higher ability MYOB accounting. Summary of the results of data analysis using ANOVA can be seen in the following table:

Table 1: Research Hypothesis Testing

\begin{tabular}{llllll}
\hline Source & \multicolumn{2}{l}{$\begin{array}{l}\text { Type III Sum ofdf } \\
\text { Squares }\end{array}$} & & Mean Square F & Sig. \\
\hline Corrected & $5406.317^{\mathrm{a}}$ & 2 & 1802.106 & 29.274 & .000 \\
Model & 363637.350 & 1 & 363637.350 & 5907.085 & .000 \\
Intercept & 3153.750 & 1 & 3153.750 & 51.231 & .000 \\
A & 3447.333 & 56 & 61.560 & & \\
Error & 372491.000 & 60 & & & \\
Total & & & & & \\
\hline
\end{tabular}

Based on the results obtained Anova table 1. The value of Fo $=51.231$ and Sig. $=0.000<0.05$, the null hypothesis (Ho) is rejected and the alternative hypothesis (H1) is accepted. This means that there is significant influence learning strategies using the tutorial is better when compared to drills on the ability of MYOB accounting student of vocational high school in Bekasi. These results are consistent with the average value of MYOB accounting capabilities that use tutorial learning strategy at 85.10 , while the average value of 
the use of learning strategies drill 70.6. The results of this study reinforced by research conducted Mema (2013) shows that the tutorial can improve student learning outcomes MYOB accounting students. Therefore, it is advisable for teachers to use in learning tutorial MYOB accounting. Through this tutorial strategies, students perform continuous active interaction with the accounting application program and the teacher only as a director or facilitator. With the interaction, students can master the subject matter easily because students can interact directly with the computer system has been programmed so that learning can be more interesting and fun to learn. This is in accordance with the opinion of Ginting (2012), states that: 1) Students gain learning services individually so that the specific problems they face can be catered specifically anyway. 2) A student can learn at a pace that suits its capabilities without having to be influenced by the other student's pace or better known as the Self-Paced Learning.

Learning is a learning tutorial using an application program that provides guidance using MYOB program to solve the problems of accounting practice. The emphasis lies in its continuous efforts to maximize the learning activity as a cognitive interaction between the students, the subject matter, and computers that have been programmed. Students are given the freedom to interact directly and follow the guidelines / tutorials provided in solving accounting. This tutorial is adventure learning (challenges), can use a variety of learning resources, emphasis on the learning process meaningful and enjoyable, sharpen cognitive and psychomotor aspects of the students, and give freedom to the students to be independent and responsible. This is according to research conducted Nursa'ban (2013) stated that the attitude of responsibility and independence in learning can be enhanced through the use of methods tutorial.

\section{Conclusion}

Based on the results of research conducted, it can be concluded that the tutorial learning strategy is better than learning strategy drill on the ability of MYOB accounting students. Therefore, teachers in improving the ability of MYOB accounting students should use the tutorials for learning strategies learning strategies of this tutorial to make students independent in learning, and students learn according to their ability indefinitely.

\section{References}

Abraham, R. \& Syaodih, N. S. (2010). Teaching Planning. Jakarta: Rineka Reserved

Adhegora, L. (2012). The Nature of Physical Exercise in Badminton Games. http://Adhegora.blogspot.com//(diunduh October 10, 2016)

Arifin, J. (2011). Revealing awesomeness Excel and MYOB for Entrepreneurs. Jakarta: Gramedia.

Ariyani, N. \& Haryanto, D. (2010). Multimedia learning in school: Learning Guidelines Inspiring, Constructive and Prospective. Jakarta: PT. achievement Pustakarya

Djamarah \& Zain. (2006). Teaching and Learning Strategies. Jakarta: Rineka Reserved.

Ginting, A. (2012). Essence Practical Learning \& Education: Professional Education and Certification of Teacher-Lecturer. Bandung: Humaniora

Heinich, R., Molenda, M. \& Russell, J. D. (1982). Instructional Media and The New Technologies of Instruction. Canada: John Wiley \& Sons, Inc.

Heryawan, A. (2010). Understanding Training Methods. Online: http://adeheryawan.blogspot.com/2010/03/metode-latihan.html. In the access date of December 9, 2016.

Roestiyah, N. K. (2008). Teaching and Learning Strategies. Jakarta: PT Rineka Reserved.

Rusman. (2011). Models of Learning: Developing Teacher Professionalism. Jakarta: Rajawali Press.

Ibrahim, R. \& Syaodih, N. S. (2010). Teaching planning. Jakarta: Rineka Cipta.

Mema, N. (2013). Independence and Learning Outcomes In the Subject Computer Accounting Using MYOB Based Media Tutorial Adobe Captivate. Journal of Accounting and Business Education, 1(4), 34-48

Nursa'ban, M. (2013). Improved Attitude Responsibility and Independence Through Student Learning Methods Tutorials In the Department of Geography Education. Journal education, 32(3), 432-443.

Sudarmanto. (2005). Analyst with SPSS Multiple Linear Regression. Bandar Lampung: Graha Science.

Suwarna, L. (2005). Micro Teaching. Yogyakarta: Tiara Discourse.

Warsito, K. (2008). Public sector accounting. Semarang: Undip. 